\title{
The impacts of ostreid herpesvirus 1 microvariants on Pacific oyster aquaculture in the Northern and Southern Hemispheres since 2008
}

\author{
M. Fuhrmann ${ }^{(1)}$, A. Castinel $^{(2)}$, D. Cheslett ${ }^{(3)}$, D. Furones Nozal ${ }^{(4)}$ \\ \& R.J. Whittington ${ }^{(1) *}$ \\ (1) University of Sydney, School of Veterinary Science, Faculty of Science, 425 Werombi Road, Camden, \\ New South Wales 2570, Australia \\ (2) Ministry for Primary Industries, 118 Vickerman Street, Port Nelson, Nelson 7010, New Zealand \\ (3) Marine Institute, Rinville, Oranmore, Co. Galway, Ireland \\ (4) Institute of Agrifood Research and Technology (IRTA), Sant Carles de la Rànita center, Crta. Poble Nou \\ km 5.5, 43540 Sant Carles de la Ràpita, Spain \\ *Corresponding author: richard.whittington@sydney.edu.au
}

\begin{abstract}
Summary
Mollusc farming is the third most productive aquaculture activity in the world, and the Pacific oyster (Crassostrea gigas) is one of the most important farmed species. Since 2008, mass mortalities in C. gigas due to ostreid herpesvirus 1 microvariants have challenged the viability of this industry in Europe, New Zealand and Australia. Ten years after the emergence of this disease, there is evidence that the industry has become consolidated into fewer, larger companies, with the displacement of small farming enterprises and loss of employment in coastal communities. Rather than seeking technical solutions, the industry has turned to compensatory production strategies, such as increasing the number of spat placed on farms, higher market prices for table oysters and direct marketing, which appear to have allowed profitability. Biosecurity policies and responses to outbreaks, including those from within the industry, have had unintended consequences for hatcheries and farmers in areas free of disease, mainly caused by restrictions on animal movements, and have not prevented global spread. There may be opportunities for better coordination of industry and government responses to epizootic disease emergence in aquaculture. There is certainly a need for increased adoption of technical advances from research, once these solutions have been adequately verified.
\end{abstract}

\section{Keywords}

Aquaculture industry - Crassostrea gigas - Government response - Herpesvirus Molluscs - Mortality - Ostreid herpesvirus 1- Oysters - Resilience - Shellfish - Societal impact.

\section{Introduction}

The successful contribution of fisheries and aquaculture to food security and nutrition depends on many interactions between environmental, developmental, policy and governance issues (1). The biggest risk for aquaculture is disease because it can suddenly reduce the volume and stability of production and therefore local livelihoods $(1,2)$, and can have enduring impacts. Throughout human history, edible oysters have sustained coastal populations, as evidenced, for example, by aggregates of empty shells (shell middens) left by indigenous peoples along coastlines in Australia and America before European settlement $(3,4)$. Even as recently as the 1940s, oysters were a staple food item for some families (5).

While edible oysters may be viewed as a discretionary food in the modern era, a study of the diseases that affect them can provide important lessons for other aquaculture sectors, which, collectively, help to ensure global food security. Mollusc farming is the third most productive aquacultural activity in the world in terms of volume, after the production of finfish (54.1 million tonnes) and aquatic plants (30.1 million tonnes). Mollusc farming generated 17.1 million tonnes for a value of US\$ 29.2 billion in 
2016 (6). The production of cupped oysters (Crassostrea spp.) in 2016 was around 5 million tonnes (6).

Like other aquaculture species, oysters are grown in large, dense populations in open systems in bays or the ocean, and the use of chemotherapeutics is usually not possible. Furthermore, vaccination cannot be used as shellfish lack an adaptive immune system $(7,8)$. Rather, disease prevention must rely on biosecurity and husbandry methods.

The Pacific oyster industry currently faces a disease syndrome caused by ostreid herpesvirus 1 microvariants (OsHV-1 $\mu$ Var) $(9,10,11)$. This virus is associated with recurrent mass mortality of Crassostrea gigas, creating a challenge for the maintenance of production and the viability of oyster farms in a number of regions across the world. Mass mortality events started in 2008 in France, then appeared throughout Europe from the Mediterranean Sea to Scandinavia $(12,13,14,15,16,17,18,19,20,21)$. In 2010, the disease emerged at a global scale, causing mass mortality in both New Zealand and Australia (22, 23).

In this paper, the authors review the consequences of OsHV-1 $\mu$ Var for the Pacific oyster farming industry, including economic and social aspects, and assess the efficiency of responses by governments and industry. In the Northern Hemisphere, the cases of France and Ireland, the two largest European producers, will be compared to a smaller producer, Spain. In the Southern Hemisphere, the two countries studied are New Zealand and Australia.

\section{Industry profiles}

In 2012, the French shellfish industry, which mainly produces oysters and mussels, comprised 2,864 companies and employed 17,715 people (8,573 full-time equivalent) (24). France is the fourth-largest producer of Pacific oysters in the world and the largest in Europe. In 2012, the 2,327 oyster farming companies produced almost 80,000 tonnes of Pacific oysters for a value of $€ 582$ million (24). Generally, farms on the west coast of France, in PoitouCharentes and Aquitaine, produce spat as the environment is adapted for recruitment, while farms in the north of France, in Brittany and Normandy, and in the south, in the Thau lagoon, are growing areas as their waters are rich in nutrients. To enable this production system, there is a dynamic transfer of batches of millions of oysters across the country (25). In 2013, 54\% of spat used by farmers were wild-caught and 46\% came from hatcheries (26).

Ireland is the second-largest producer of Pacific oysters in Europe, with production of 9,900 tonnes in 2017 for a value of $€ 43.3$ million (27). Farming occurs in 43 bays distributed around the coast from County Louth to
County Donegal. Combined oyster employment is close to 1,300 people, mainly on C. gigas oyster farms. Just under half of this total is full-time employment (27). The majority of the farms are small, producing $<10$ tonnes per year. As there are no notable wild populations of Pacific oysters in Ireland, the industry relies on spat produced in hatcheries, mainly in France and to a lesser extent in the United Kingdom (UK) and Ireland. Some wild-caught spat from France are also used.

Spain has the greatest aquaculture production by volume in Europe, and the third by value after France and Italy (28). In 2016, aquaculture employed 17,811 people working in 5,105 establishments, 4,782 of which were dedicated to shellfish (28). By volume, mussel production dominates Spanish shellfish aquaculture and in 2016 the production of Pacific oysters in Spain was only 635 tonnes with a farm-gate value of $€ 3.8$ million. Crassostrea gigas production occurs mainly in Catalonia, predominantly in the bays of the River Ebro Delta (Alfacs and Fangar Bays), but this species is also cultivated in Andalusia, Asturias, Cantabria and Valencia. The oyster industry is based on small family businesses. In Catalonia, most producers combine aquaculture with another form of agriculture, principally rice (29). Spat are obtained from the wild and from hatcheries, either local or imported, mainly from France.

In New Zealand, in 2015, the aquaculture industry employed over 3,000 people working in the three main sectors - green-lipped mussels, Chinook salmon and Pacific oysters - generating around NZ\$ 500 million in revenue that year. The Pacific oyster sector represents only a small fraction of the total production and farms are concentrated in the northern part of the North Island, with only a few operations at the north of the South Island. The vast majority of the spat used are wild-caught. However, some spat are produced by a commercial hatchery in the north of the South Island. Pacific oyster production was 1,834 tonnes in 2017 (30).

In Australia, edible oyster production comprises the Sydney rock oyster (Saccostrea glomerata) and the Pacific oyster, together with a few other minor species, and takes place mostly in New South Wales, South Australia and Tasmania (31). In 2015-2016, the total oyster production was 11,345 tonnes, valued at AUS\$ 97,041 million (32). Tasmania provided $35 \%$ of the oyster production volume and its hatcheries supplied $95 \%$ of Pacific oyster seed for the entire country (33). The oyster industry directly employed around 2,000 full- and part-time employees.

\section{The emergence of OsHV-1 $\mu$ Var}

Mass mortality events related to OsHV-1 $\mu$ Var were first recorded in Europe in 2008 and have recurred annually. 
In France, mortality reached $80-100 \%$ in 2008 (10) and in 2015 it was reported to be $50-60 \%$ (34). In Ireland, in 2009 , median mortality was 37\% (18\%-65\% quartiles) but varied greatly between and within bays (17). In Europe, mass mortality characteristically commences when the water temperature reaches $16^{\circ} \mathrm{C}$ and is observed up to $24^{\circ} \mathrm{C}$ (10). Thus, in France and Ireland, mortality begins in the south and spreads northwards as waters warm each spring and summer. In cooler years, mortality may not reach the more northern bays in Ireland. In France, the pathogen has spread nationally, probably due to oyster translocations during the production cycle, and mortality affects all regions of the country (34). In Ireland, the virus was first detected in three bays in the south and south-west (35), but since then it has spread along the coast. By 2018, the number of infected bays had risen to 34 . The reasons for spread are not clear, but may include the use of infected French spat (17), biosecurity failures such as sharing equipment and personnel between sites, and proximity to infected bays or to effluent from depuration plants receiving shellfish stocks from affected bays.

In 2008, episodes of mortality in the Ebro Delta bays in Spain reached $100 \%$ and were attributed to OsHV-1 (19, 36). In 2010, the detection of OsHV-1 in Galicia caused the temporary closure of farms and the only hatchery cultivating C. gigas, due to the high mortalities (A. Villalba, personal communication). OsHV-1 has not been detected in wild populations of $C$. gigas but has caused mass mortalities in two cultivation areas of Ria de Arousa. No mortalities have been detected in the Ria de Vigo so far (37). In Andalusia, the virus has been detected in three rivers and mortality has been attributed to OsHV-1, but the extent of the impact is still unknown (J. Navas Triano, personal communication).

In New Zealand, mortality commenced in young oysters in March to April 2010 in the North Island, but was not reported to the government until November 2010, when it was confirmed to be associated with OsHV-1 $(38,39,40)$. The disease had immediate dramatic impacts on production, with up to $100 \%$ mortality of spat (39). By January 2011 , 15 of the 18 production areas in the North Island were affected by mass mortalities. Farmers lost more than 70\% of their stock between 2010 and 2012, and are still facing substantial losses of spat (40-60\%) (41). The sole South Island location reporting high mortality in December 2010 was the only New Zealand commercial hatchery; OsHV-1 was identified in larval batches produced from broodstock that had been transferred from the North Island before November 2010. Hatchery production resumed in February 2011. There has been no report of mass mortalities elsewhere in the South Island, but the virus was allegedly detected in samples from an area in the north of the South Island in 2010 (40) and later identified in farmed oysters and nearby wild oysters, early in 2016 (42).
In Australia, OsHV-1 first caused a mass mortality of Pacific oysters in December 2010 in the Georges River (New South Wales) (23). Then, in January 2013, the disease appeared $50 \mathrm{~km}$ north in the Hawkesbury River estuary (43). The impact of this disease has been devastating in both estuaries, with near-total stock losses in the first year in each case. OsHV-1 subsequently emerged in January 2016 in Tasmania, causing mass mortality on farms in the southeastern region (44), but the northern and north-eastern regions remain unaffected. In February 2018, the virus was detected during an investigation of mass mortality of wild C. gigas populations in South Australia, in the Port River near Adelaide, $60 \mathrm{~km}$ from the nearest farming areas (45). Subsequent surveillance testing has shown the absence of OsHV-1 in all farming areas in South Australia (45).

\section{Effects of disease on production and prices}

In general, it is quite difficult to find standardised information for Pacific oyster production in any country. However, in both the Southern and Northern Hemispheres, the loss of production in the first year after the appearance of OsHV-1 $\mu$ Var was dramatic. In France, production decreased by 25\%: from 107,390 tonnes in 2001 to 79,220 tonnes in $2012(24,46)$. In Ireland, annual production increases, which were strong before 2007, slowed after 2008. In Catalonia, Spain, production in the Ebro River area has still not recovered to the 2006 level of 816 tonnes; it fell to 138 tonnes in 2011 (36) and was estimated at 283 tonnes in 2016.

In New Zealand, Pacific oyster production (harvest, green weight) declined from 2,708 tonnes in 2009 (47) to 1,834 tonnes in 2017 (30). In Australia, data are scarce, but it is clear that the total production of Pacific oysters in New South Wales was reduced by $48 \%$ within three years of the first outbreak. In the Hawkesbury River, Pacific oyster production, measured by declared supply from farms to the market, dropped from 186,093 dozen in 2012/2013 to fewer than 5,000 dozen from 2014 to 2016. It then rose to 15,492 dozen in 2017/2018 (48).

As a result of the mortality among juvenile and adult oysters when the disease first emerged, and the shortage of spat, there has been a decline in market volume, which has led to an increase in the price of oysters. This has assisted those farmers who remained in business by compensating for some of their production losses. In France, the price of oysters increased from $€ 4.93 / \mathrm{kg}$ in 2001 to $€ 7.78 / \mathrm{kg}$ in 2012 (24). The price shift happened in 2010 when the surviving spat of 2008 , i.e. the cohort first affected by mass mortality, reached market size but in low quantities (24). 
In Ireland, the market price increased from $€ 2.02 / \mathrm{kg}$ in 2008 to $€ 4.3 / \mathrm{kg}$ in 2017 (27). In Spain, the price of C. gigas has increased substantially in the last few years to reach $€ 6 / \mathrm{kg}$, a level that is more profitable than in the period before the production losses (J. Alcala, personal communication). In New Zealand, the market value of Pacific oysters has also risen since 2011 (Anon., aquaculture industry, personal communication). In December 2017, there were shortages of oysters in the markets around Australia and prices climbed, according to media reports (49). While production has decreased in Australia, the value and market price of Pacific oysters have increased, placing the industry's revenues close to pre-outbreak figures.

\section{Response from government}

\section{Direct financial support}

In 2009 , to support farmers affected by a mass mortality of spat, the French Government provided a royalty rebate for farmers growing spat and juvenile oysters; $€ 2.5$ million for an expense relief fund for some companies; $€ 2.5$ million for an interest subsidy of $2.5 \%$ for shortterm loans for oyster farmers to fund reseeding operations; and further support under the National Fund for the Guarantee of Agricultural Calamities (FNGCA) (50). The FNGCA compensates for the material damage caused to farms by uninsurable agricultural disasters of exceptional importance, due to abnormal variations in the intensity of a natural agent. A budget of $€ 39$ million was mobilised for this (50). Between 2008 and 2010, around $€ 135$ million has been granted by the French state to the industry (34).

In Australia, the level of financial support varied between states. In New South Wales, apart from minor concessions on annual farm lease fees, there was no specific state government financial support for farmers. This was met with dismay by the farmers, as it contrasted with a support programme implemented in New South Wales in 2005 to help farmers in the Hawkesbury River estuary overcome the effects of a disease epizootic in Sydney rock oysters, caused by Marteilia sydneyi (QX disease). Although the government did not give any reasons for this decision, it is likely that the potential for the spread of OsHV-1 to other estuaries (based on the well-publicised French experience) created an expensive scenario for financial compensation that could not be sustained politically. However, when OsHV-1 disease emerged in Tasmania, a state considered to be economically disadvantaged, the Australian Government allocated AUS\$ 1.47 million to provide diagnostic tools and support farmers in managing the disease (31). Other support services were also made available in the form of farm household allowances, farm management deposits, taxation measures, the Rural Financial Counselling Service, farm finance concessional loans, a programme to manage farm risk, and enhanced social support (31).

In April 2016, three months after the mortality event commenced, the Tasmanian government announced a recovery package of AUS\$ 7.6 million to help Pacific oyster growers, nurseries and hatcheries (33). The state government provided fee relief, farm clean-up assistance of up to AUS $\$ 4,500$ per hectare, an AUS\$ 5 million concessional loan scheme and AUS\$260,000 to purchase testing equipment to provide laboratory results on the presence or absence of OsHV-1 $(31,33)$. In South Australia, in 2018, the state government waived AUS\$ 1.6 million in annual aquaculture lease fees and licence fees over two financial years and gave AUS\$320,000 to two small oyster hatcheries to boost the production of spat. This fee relief was in response to the shortage of spat due to the Tasmanian outbreak. As an emergency measure, the South Australian Research and Development Institute (SARDI) received AUS\$150,000 to produce spat (51).

\section{Funding research}

In general, governments and research institutions have undertaken studies that aim to improve our understanding of OsHV-1 by characterising the virus and the epidemiology of the disease that it causes. One of the solutions proposed to help oyster farmers to cope with the disease is the use of genetically selected oysters $(8,31)$, and grants for breeding programmes have been provided in various countries.

At the European scale, two research projects, Bivalife (Controlling Infectious Diseases in Oysters and Mussels in Europe; 2011-2014) and VIVALDI (Preventing and Mitigating Farmed Bivalve Diseases; 2016-2020), were granted $€ 4,555,673$ and $€ 5,414,417$ respectively, at least partially in response to the OsHV-1 issue $(52,53)$. The European Union (EU) contributed $€ 2,995,636$ to Bivalife and $€ 4,503,082$ to VIVALDI. These projects aimed to prevent and mitigate farmed bivalve diseases and focused on the mass mortality of Pacific oysters due to OsHV-1.

In France, under pressure from the industry, the state invested in research programmes to identify the nature and causes of these viral outbreaks and to explore genetic selection for resistance through public and private organisations, including the French Research Institute for the Exploitation of the Sea (IFREMER), universities and private hatcheries $(34,54)$. Some private French hatcheries and the Comité National de la Conchyliculture (CNC) have their own selection programmes (8).

In Ireland, the Marine Institute funded a study to identify management and environmental factors associated with mortality, and further studies were funded in 2011 and $2012(17,35,55)$. Growers in areas where OsHV-1 has 
been detected are largely dependent on French hatchery stock, which seem to show a better survival rate than oysters produced in UK and Irish hatcheries. In 2015, sentinel trials were run in Ireland under a nationally funded programme ('Reducing the impact of pathogens and disease in the Irish oyster industry to support the sustainability and growth of the sector' [REPOSUS]), supported by the Food Institutional Research Measure (the funding mechanism of the Department of Agriculture, Food and the Marine). These trials demonstrated the difference in performance between the French stocks and the unselected Irish stocks. The hatchery-produced, diploid, naive Irish stock were compared with the French hatchery stock in four OsHV-1-affected bays. In three of the four sentinel bays, spat mortality exceeded $90 \%$ in the naive Irish stock, compared to less than $50 \%$ mortality among the batches of French seed (C. O’Toole, personal communication).

The Spanish central government financed the project HERPEMOL to develop common diagnostic criteria and an epidemiological assessment. The local Galician government continued the project and, with its own regional funding, supported an epidemiological study to investigate alternative management strategies and genetic selection for resistance. The Catalonian government also commissioned research by extending a previous programme (BIVALDAR) to focus on the problem of mass mortalities.

In New Zealand, epidemiological findings have remained empirical and ad hoc, and to date there has been no integrated research programme exploring the epidemiology of OsHV-1 across New Zealand. However, in 2011, the New Zealand Government allocated NZ\$150,000 to a selective breeding programme to enable virus resistance trials $(56,57)$, and in 2012 allocated NZ\$ 407,000 from the Sustainable Farming Fund to the Oyster Industry Modernisation Project in partnership with the industry organisation, Aquaculture New Zealand (56). In 2013, the government allocated funding to the Cawthron Institute for research on shellfish production and aquatic animal health, in partnership with other science organisations, through the Cultured Shellfish Programme ( NZ\$ 21 million over seven years) (58). This was followed by a programme called 'Optimising detection, diagnostic, prediction and management strategies for New Zealand aquaculture health' in 2017 ( NZ\$ 15 million over five years) and the Shellfish Aquaculture Platform in 2018 (NZ\$ 12 million over six years). A key component of these programmes is that they include, among other features, an exploration of selective breeding of Pacific oysters for OsHV-1 resilience, which accounts for up to a quarter of the funding.

In Australia, after the New South Wales outbreak in November 2010, federal government and industry funding, managed by the Fisheries Research and Development Corporation (FRDC), was prioritised and applied from
July 2011 to conduct a series of research projects to better understand the disease, prevent its spread and mitigate losses (59). This resulted in a succession of epidemiological projects funded by the government and/or industry and a university through the FRDC (FRDC Project 2011/053: AUS\$ 130,000; Project 2012/032: AUS\$ 448,382; Project 2014/040: AUS\$ 398,700).

In Australia, the breeding programme became a dominant feature of the industry strategy to deal with OsHV-1. This solution became firmly embedded in the thinking of individual farmers after they visited France (60) and was promoted by their industry association, Oysters Australia. Funding from the oyster industry in New Zealand was pooled with Australian funds and used to validate a laboratory infection model to assist the selection of resistant oysters (FRDC Project 2012/052). Additional government funding, managed by the FRDC (Project 2012/760), enabled field trials with selected family lines. The private company Australian Seafood Industry (ASI) selectively bred the oysters and provided improved broodstock to hatcheries $(61,62)$. However, due to mortalities in New South Wales and Tasmania, its income from a levy on spat sales was reduced (31). A Cooperative Research Centre (CRC) Project (CRC-P) was then established with AUS $\$ 3$ million in federal government funding to enhance the breeding programme and disease control (63).

\section{Risk management, biosecurity and communication}

Solutions to prevent the spread of infectious disease include the management of animal and equipment movements and surveillance for early detection and response.

In Europe, the European Commission (EC) introduced relevant animal health measures which were implemented by its Member States: Council Directive 2006/88/EC, Commission Regulation 2010/175/EC, and Commission Decision 2011/187/EC, which make provisions for the control of OsHV-1 $\mu$ Var available to Member States $(64,65,66)$. The effectiveness of these measures is unclear.

In France, transfers of oysters during the production cycle led to broad dissemination of the pathogen throughout the country (34), as well as to other countries (e.g. Ireland and Spain) that depended on French spat. In 2008 and 2009 , certification for the detection of OsHV- $1 \mu$ Var was not required for oyster transfers because the herpes virus was not regulated (67). In 2009 and 2010, the French Ministry of Agriculture banned shellfish transfers between farming areas during the critical period of mortality (34, 67 ), adversely affecting the production cycle and forcing hatcheries to retain their stock in the nursery (67). However, these measures were ineffective as all French farming areas 
were affected by mass mortality $(34,67)$. Surveillance for OsHV-1 has been achieved in France by a national network of accredited laboratories, led by the National Reference Laboratory and known as the Mollusc Pathology Network (Réseau de pathologie des mollusques or REPAMO) (68), and by the IFREMER shellfish observatory, RESCO, which studies the output of Pacific oysters from aquaculture in the main French mollusc-farming areas (10).

In Ireland, containment measures were implemented in 2009 under Council Directive 2006/88/EC (64) and, after consultation with the industry, further legislation was sought to control the disease. A surveillance programme for the early detection of OsHV-1 $\mu$ Var was implemented under the new legislation and oyster movements into unaffected bays were restricted. Twenty-five unaffected bays were enrolled in the programme in 2010 but, during its first year, six of these bays were identified as positive, three of which were linked to stock inputs from France before 2009. From 2011, the surveillance programme continued under Commission Decision 2011/187/EC (66) but the disease continued to spread and, by the end of 2017 , only nine bays remained free of the virus. Those bays are restricted to buying seed from bays of an equal health status (e.g. areas which are also in a surveillance programme) and many producers question whether the benefits of remaining in the programme are outweighed by this requirement. The cost of this stock is considerably higher than that of stock from other sources and moreover it has become increasingly difficult to secure. The UK and Ireland were the only countries that put surveillance programmes in place under EC regulation, and this may have allowed them to maintain OsHV-1 $\mu \mathrm{Var}$-free areas. Passive surveillance in Ireland is in place across all oyster-growing areas through a risk-based surveillance scheme, compulsory notification, and investigation of abnormal mortality, as required under Council Directive 2006/88/EC (64). Extensive testing for the virus has taken place since 2008 and the costs have been absorbed by the state.

In Spain, there is no official surveillance in place in Catalonia as OsHV-1 is not a listed pathogen under the EU or Spanish legislation but there is passive surveillance based on farmer notification of mortality. The Catalonia Shellfish Growers' Association (FEPROMODEL) is developing selfregulation and centralised shipment of spat. In 2012, FEPROMODEL opened a Sanitary Animal Defence office to collaborate with Competent Authorities in the control and prevention of shellfish diseases. Galicia imposed a ban on oyster movements from farms affected by OsHV-1 in Ria de Arousa but kept it for only one year (A. Villalba, personal communication).

In New Zealand, movement controls were put in place as soon as mass mortalities were reported in late 2010 and a delimiting survey was carried out (39) but it soon became evident that these measures would not be effective, given the scale of the transfers already occurring between affected and unaffected areas (41). Limited surveillance was conducted by the Ministry for Primary Industries (MPI) in 2016 in the northern part of the South Island after some abnormal mortalities were reported by farmers. Surveillance remains based on voluntary reporting of abnormal mortality by the industry. In 2016, MPI published a handbook to guide fish farmers in managing animal movement when diseases occur. Recommendations include importing animals from areas with equal or better disease status and exporting animals to areas with equal or lesser disease status (41).

In Australia, biosecurity management has been stricter than in Europe. The New South Wales government response to the first outbreak of OsHV-1 in 2010 was swift and prohibited movement of oysters and farming equipment out of the affected area. An independent outbreak occurred in 2013 in the Hawkesbury River (43). It was not linked to oyster-farming activities, as biosecurity measures were in place in the oyster industry in New South Wales. The pathway may have been particle movement through coastal connectivity due to tides and currents, commercial shipping, recreational boating or domestic seafood translocations (69). The movement restrictions in New South Wales were apparently successful because, by 2018, there were no reports of OsHV-1 on farms beyond the Georges and Hawkesbury River estuaries.

After the mortality event in Tasmania in January 2016, the New South Wales government banned the importation of spat from Tasmania, except into the two OsHV-1-affected estuaries. However, the costs to Tasmanian hatcheries of the general health certification necessary for the translocation of spat to New South Wales, and the inability of farmers in the affected estuaries in New South Wales to pay for large numbers of spat, precluded spat supply from Tasmania to New South Wales. In Tasmania, a local ban on the sale of spat by hatcheries was imposed by the Tasmanian government at the beginning of the outbreak. This was lifted approximately three months later for sales within Tasmania, relieving some of the pressure on farmers who were desperate for new stock. South Australian oyster farmers depended on regular consignments of spat from the hatcheries in Tasmania but restrictions on the movement of all live oysters and farming equipment from Tasmania to South Australia were implemented in 2016 and have been extended to March 2019. This has resulted in a severe shortfall of spat in South Australia (51).

There was nationally coordinated surveillance in Australia in 2010 to confirm the absence of OsHV-1 in all farming areas, except the disease-affected Georges River estuary in New South Wales (70). Active surveillance has since taken place in Tasmania (2016) and South Australia (2018) to confirm the extent of OsHV-1 spread. Passive surveillance 
occurs nationally; the occurrence or suspicion of OsHV-1 must be notified in accordance with legislation in each state, and unusual mortality events are notifiable under the conditions of aquaculture licences.

There is a problem in accurately defining what is meant by abnormal mortality in oysters $(31,40,71)$. Consequently, mortalities may not be reported to the relevant Competent Authority in a timely or uniform manner (41), which hampers passive surveillance and the early detection of OsHV-1 (71). Furthermore, oyster farmers often do not have easy access to their oysters and the low frequency of observation might delay early viral detection (71). In France, financial compensation appeared to be the incentive for reporting mortality, but this was countered by the habituation effect (in which repeated exposure to a stimulus decreases the response) and a lack of awareness of the objectives of the reporting system (71).

In Ireland, the Competent Authority (the Marine Institute) implemented trigger levels for mortality reporting in 2016. While there is some level of underreporting and late reporting of mortalities, in general, this is not a significant problem. The industry in Ireland is small and communication between the Competent Authority, the National Reference Laboratory and producers is good. Producers generally understand the need to report mortality. Furthermore, notification of mortality is compulsory and the requirements for reporting are reinforced through biennial inspection of all Pacific oyster-growing sites in the country through the risk-based surveillance scheme.

In Australia, disease surveillance and control are managed at the state level; in New South Wales, Tasmania and South Australia, it is compulsory to report mortalities higher than $5 \%$ to $10 \%$. In South Australia, a sampling strategy is described in which oysters are analysed by the Primary Industries and Regions South Australia (PIRSA) laboratory $(72,73,74)$.

A further action undertaken by the Australian Government has been to convene a communications network comprising representatives of the Commonwealth Government Department of Agriculture and Water Resources; primary industries departments in New South Wales, Tasmania and South Australia; the main oyster farmer organisations in each state; representatives from hatcheries; and research and development providers. Known as the 'Pacific Oyster Health Management Working Group of the Subcommittee on Aquatic Animal Health', participants meet by teleconference at least twice annually to review current issues and to discuss progress in the national response to OsHV-1.

\section{Response from industry}

\section{Increased supply of spat}

One solution to OsHV-1 mass mortality that suits mainly larger farming enterprises is to increase the stocking rate, allow mortality due to OsHV-1 to occur, and then cultivate the survivors. There is evidence of the uptake of this approach in France, Ireland, New Zealand and Australia. The experience in Europe, New Zealand and Australia is that spat can be safely produced in endemically affected waters because the virus can be excluded from hatcheries by treating incoming seawater and disinfection $(69,75)$.

In France, since 2008, farmers have increased the level of stocking of spat in estuaries by purchasing more spat from hatcheries, $80 \%$ being triploid (24). This compensates for a high mortality rate and maintains a constant level of output (34). The demand for more spat has led to an increase in the number of hatcheries. In 2012, eight hatcheries, 34 nurseries and 14 hatchery-nurseries produced 3.6 billion $C$. gigas seed, a number five times higher than in 2001 (24). At this point, seed from hatcheries represented $49 \%$ of the total national seed production, in comparison to $16 \%$ in 2001 (24). In 2012, about 1,027 companies purchased hatchery spat, compared to 377 companies in 2001. Farmers in France also purchased more wild-caught spat. The collection of wild seed was improved by increasing the number of spat collectors by a factor of three and acquiring new leases $(24,34,54,76)$. In 2012, a total of 1.8 billion spat were wild-caught, a $70 \%$ increase compared to the 2001 total (24).

In Ireland, several hatcheries produce diploid Pacific oysters to supply local farmers. At present, the majority of this stock is sold to OsHV-1-free areas in Ireland but this potential market has shrunk as more bays test positive for OsHV-1 and the survival of these oysters when introduced into OsHV-1-positive areas appears to be low. In 2012, the Marine Institute and Bord Iascaigh Mhara (BIM), the Sea Fisheries Board, funded a programme to produce diseasefree tetraploids to enable production of natural triploids by Irish hatcheries. The first commercial batches of triploids became available in 2015. This stock has been taken up by farmers in bays which remain free of the virus. There are only a small number of hatcheries in England and Ireland that are able to supply diploid and triploid oysters to these virus-free areas. All of these hatcheries are of a much smaller scale than those in France, and in 2018 the cost of seed was reported to be four times higher than in France.

In Spain, attempts to establish new hatcheries locally have met with varied success. The lack of local spat has led some Galician farmers to buy larger spat that have already survived one mass mortality event in France. Such large 
spat are more expensive than small spat but mortalities are lower (A. Villalba, personal communication). Other producers have avoided French importations, by using wild-caught spat from areas where C. gigas has become naturalised (37).

In contrast, in New Zealand, wild-caught spat are the main source of stock for Pacific oyster farmers and only the largest companies use hatchery spat. One such company uses a non-affected location in the South Island in summer - though OsHV-1 was recently detected in that area (42) as a relay point to allow hatchery spat to grow safely until winter, when they can be transferred to the North Island to grow to a marketable size. The investment required to move from wild-caught spat (stick culture) to hatchery spat (single seed) is uneconomic for most growers, due largely to the high costs of labour and cultivation equipment (41).

In Australia, farmers had relied on hatcheries in Tasmania to supply most $C$. gigas spat. The consequences of OsHV-1 for these hatcheries have been the sequential loss of their markets and the need to respond to biosecurity demands. Their New South Wales market was progressively lost from 2010 as it became impossible to farm C. gigas in OsHV-1affected estuaries. Then, in 2016, the emergence of OsHV-1 in Tasmania caused significant disruption. Spat orders declined suddenly as local demand fell and biosecurity considerations led to the complete loss of markets in New South Wales and South Australia. The two leading commercial hatcheries in Tasmania made capital investments in improved biosecurity to meet local demand, and later opened new hatcheries in South Australia to enable them to continue to supply that market. These hatcheries began production in 2017-2018.

Also in South Australia, two existing, small-scale, commercial hatcheries expanded production volumes using government funding. Larger quantities of spat were produced but without expansion of nursery capacity. Thus, in 2017, all of the hatchery spat produced in South Australia were shipped to farmers at $2-3 \mathrm{~mm}$ in size instead of the larger size, of which farmers had prior experience and the equipment to handle (5-6 mm). Survival rates were low.

The business model for hatcheries in Tasmania requires a viable farming industry in both Tasmania and South Australia but farmers in South Australia are at great risk due to the continuing spread of OsHV-1, while those in Tasmania have not yet settled on new management approaches for farming in the face of the disease. Demand from farmers in New South Wales alone would be insufficient to sustain the hatcheries in either Tasmania or South Australia, but movements of spat from Tasmania to New South Wales were permitted again in 2018 under strict biosecurity guidelines.

\section{Changes in rearing practices}

In general, oyster farmers responded quickly to OsHV-1 outbreaks and some have experimented with new rearing practices. In France, little information is publicly available, due to the competitive farming environment, but oyster farmers are thought to have changed growing height and oyster density and diversified the farmed species (e.g. mussels, algae) (54). In Ireland, holding spat higher up the shore to slow growth reportedly improved survival at some sites. Producers have also identified places where spat survival is higher and adapted their growing areas accordingly. One significant shift has been a move towards taking seed in the autumn instead of spring (as was the practice before 2008), meaning that oysters are larger and more resilient in the summer when outbreaks occur. This adaptation of husbandry practices in conjunction with greater inputs of spat and the increased resistance of oysters has allowed many oyster producers to continue farming.

In Spain, educating producers to accept change and research to define the timing and husbandry conditions (placement in the estuary depending on the water temperature profile, spat size and growing system) that would reduce mortalities due to OsVH-1 has continued. New husbandry protocols have been widely adopted by the sector, and mortalities have dropped from the $80 \%$ levels of 2014 to $2-8 \%$ when these protocols are followed (36). Most producers cultivate both mussels and Pacific oysters so that activity continues throughout the year. In Galicia, some producers have abandoned Pacific oyster culture.

In New Zealand, a limited number of farmers changed their practices to limit disease spread and associated impacts on production (40). Some reduced the frequency of handling during OsHV-1 outbreaks; others reduced oyster densities on the farm. With the recurrence of seasonal mortalities, the production cycle has reportedly increased from as little as eight months before OsHV-1 emerged to as long as 14 months nowadays.

After applied research in Australia, by early 2016, the farmers in the Hawkesbury River, New South Wales, were ready to trial commercial production, using modified husbandry procedures based on new knowledge about the seasonal window of OsHV-1 infection, safe locations that had been identified in the estuary, and elevated growing heights to reduce exposure to the virus. However, the first commercial shipments of spat were delayed until 2018, due to New South Wales state government biosecurity restrictions being imposed on spat originating from Tasmania. In Tasmania, following an epidemiological assessment of OsHV-1 risk factors (44), 88\% of farmers changed their management practices by altering their handling regime, stock density, stock amount, stock type or time of placement of oysters (77). On the majority of leases, farmers reduced stocking 
density by $35 \%$ but this was primarily the result of low stock availability (77). By 2018, some larger Tasmanian farms increased their numbers of stock spat, with the objective of growing the survivors after exposure to OsHV-1. This approach requires a greater initial financial outlay on spat, as well as a larger farm lease area, more labour and increased infrastructure to stock and manage the greater spat numbers, and so this method may be suited only to larger farming companies.

\section{Impact on farming businesses and society}

In Europe, the consequences of the OsHV-1 outbreak on employment varied among countries and thus are difficult to assess.

In France, the crisis triggered the collapse of the small farms, but the surviving businesses may be more profitable than before 2008 (34). The resilience of farms to OsHV-1 outbreaks depended on a combination of factors, including the natural environment and pre-existing hazards at each farm location, because these influenced the status of each farm at the time of the outbreak and its capacity to adapt $(54,76)$. In $2014,57 \%$ of farmers reported stable or higher profits after the crisis while $32 \%$ saw a decline in their sales and $8 \%$ faced higher debt levels (34). The mortality rate was still 50-80\% eight years after the first outbreak (34). Market prices have increased significantly, resulting in better profitability levels for the surviving firms (34). Farmers increased their direct sales of oysters to consumers between 2001 and 2012. This was more profitable, as intermediaries in the market offer lower prices to farmers than direct sales (24). Mass mortality due to OsHV-1 is now part of the production cycle and the remaining French farmers cope with it by adapting their business model to the presence of the virus. However, the variability of mortalities from year to year is still challenging for farmers (78). In terms of employment, between 2001 and 2012, the shellfish industry lost 25\% of its companies (corresponding to 887 companies), and 3,947 employees, but the companies tended to get bigger, i.e. there was a concentration of farming activity in fewer businesses (24). It was also reported that, between 2008 and 2011, the number of shellfish-farming companies slightly decreased, but the number of jobs remained fairly stable (34). As these data deal with the entire shellfish industry, it is difficult to estimate the effect of OsHV-1 on employment in the Pacific oyster farming industry.

In Ireland, the industry has evolved as a consequence of the losses and additional financial uncertainty created by OsHV-1, as well as licensing problems, biotoxin events and other pathogens. Producers in affected bays adapted by increasing their spat inputs and altering their husbandry practices but not all producers were able to adapt. Mortality related to the virus appears to have decreased since 2014.
Investment continues to be strong and the industry has continued to grow, albeit at a slower pace than before 2008. Investment has largely come from French companies looking to diversify their risk by holding stock in both France and Ireland. Employment has risen steadily over this period, in line with increasing production and the emergence of French ownership.

The appeal of growing oysters in the cooler Irish waters was what drove French companies to seek farming sites in Ireland (67). Procedural issues within the Irish licensing system made it almost impossible for these companies to secure new licences and so the only option was to negotiate with the existing Irish licence holders. For many small Irish operators this provided an attractive option: they could continue to work the site, but without the same financial risk. There has also been an increase in Irish producers rearing oysters on contract for French companies. In other cases, the licences have been sold to French companies that manage the day-to-day running of the farm. The result has been that some of the larger French companies now control multiple sites across Ireland and the number of smaller producers operating single sites has fallen. This has implications for biosecurity as oysters are moved more frequently between sites within the country than they were before 2008. Additionally, French operators move stock between their Irish sites and sites in France.

Over the last decade in Spain, OsHV-1 generated neither unemployment nor abandoned businesses (29), but farms have grouped together to create bigger companies. Although small producers suffered from the mortalities, abandoning aquaculture was not an option. Most of them continued to produce, combining aquaculture and agriculture under the business structure of bigger producers in a mutually beneficial arrangement. In Catalonia, the industry is in better economic shape than before the OsHV-1 crisis because production is much lower but of higher quality, and therefore more profitable. Producers have diversified their business model to market to consumers directly (through rural tourism, shops and restaurants) under a common brand. The small farmers sell oysters to the larger ones, who have better equipment, depuration plants and a marketing strategy to reach the supermarket chains. Generally, production has become concentrated in fewer hands at a more professional level. FEPROMODEL has set compulsory quality standards to commercialise local products and this, along with high demand and low supply, has had a positive impact on prices. The clustering together of small and large producers makes it more feasible to buy machines, negotiate loans and, in general terms, operate as a medium-sized company. However, restructuring and increased profitability have not incentivised producers to look towards long-term sustainability, nor to invest in closing biological cycles, biosecurity and/or biodiversity protection. 
In New Zealand, the severity of the 2010 OsHV-1 outbreak led to the bankruptcy of some businesses, and farms were left abandoned. Most farm employees were made redundant in the worst-affected areas of the North Island, either as a direct result of farms ceasing activity or as a consequence of larger companies restructuring their production and relocating their operations out of affected areas (40). The main social impact has been unemployment in local communities that were strongly reliant on Pacific oyster farming and processing.

This was the case in the Northland region, which has a small regional economy strongly linked to primary industries. Before the disease event, oyster farming and processing directly contributed NZ\$19 million to Northland's regional income and created 336 full-time equivalent jobs (79). These figures do not include indirect economic benefits such as supporting businesses. When the disease hit the region in 2010, an oyster-processing plant closed, making 66 staff redundant, as there were no oysters left to harvest. The crisis resulted in local farmers leaving the industry, either for retirement or to seek employment in other business sectors, including outside the region. Smaller farmers stopped their activity and changed employment (80). Options for recovery were particularly limited for small farmers, who generally had very little, if any, cash flow to invest in new infrastructure or hatchery spat. For the large oyster companies, the OsHV-1 outbreak came as a business opportunity as they could consolidate operations by purchasing smaller farms. Anecdotally, some farmers developed a resourceful coping strategy by processing and selling oysters locally themselves, running oyster-farm tours and opening their own local outlets (80). Even though some spat-catching areas remained free of the virus, farmers there were unable to sell their spat to their usual customers, who were reluctant to take a risk with naive spat as the mortality rates were initially $100 \%$. This resulted in indirect impacts on businesses supplying spat in OsHV-1-free areas $(40,41)$

In the Georges River estuary, New South Wales, Australia, in 2010, commercial production of $C$. gigas ceased within a few days after the mass mortality and casually employed farm staff were dismissed. One farm closed, another reverted to farming the slower-growing Sydney rock oyster, while the third business changed to general seafood wholesaling, using a land base previously used for processing oysters. In January 2013, the Hawkesbury River estuary was affected by a mass mortality. Within a few days, casual farm workers were dismissed, and banks required repayment of debt, forcing some farmers to cease their operations completely and liquidate assets, including personal assets. Most of the farms closed immediately and only three of 14 businesses continued oyster production, albeit in a limited capacity, by switching to Sydney rock oysters and taking off-farm employment. Capital investment in farms and equipment ceased. By 2018, commercial production of C. gigas in the Hawkesbury River estuary was only just resuming, using modified husbandry procedures that have flowed from recent research. A large, industry-funded commercial trial has been proposed for 2019, using the first commercially available, genetically resistant spat from a hatchery in Tasmania, which will be stocked on nine different farms in the Hawkesbury River and the one remaining farm in the Georges River estuary.

The estimated direct cost of the 2016 OsHV-1 outbreak in Tasmania exceeded AUS\$ 12 million and around 80 people lost their jobs (31). Only part of the state was affected and, as some companies operated in both the affected (south) and unaffected (north, north-east) regions, they were able to continue farming. Moreover, outbreaks after 2016 were less severe than the index case. After the 2016-2017 summer season, 75\% of oyster businesses rated their operation as strongly viable (77). One of the large hatcheries announced an attempt to raise capital in 2018 to enable the acquisition of oyster farms to create a vertically integrated business (Shellfish Culture Tasmania, personal communication). The occurrence of OsHV-1 in Tasmania in January 2016 had an immediate impact on farmers in South Australia, who had relied on the supply of spat from Tasmanian hatcheries. No new spat could be stocked in South Australia, which inevitably led to a shortage of market-sized oysters one to two years later (81). This situation is unresolved.

\section{Effectiveness and future recommendations}

\section{Biosecurity}

Biosecurity has not prevented the occurrence of mass mortalities due to OsHV-1 $\mu$ Var in isolated countries, such as Australia and New Zealand, where stringent border biosecurity policies have been in place for decades. One reason may be that the primary source of infection is not able to be mitigated by current biosecurity arrangements. Recent analysis has suggested that environmental and anthropogenic factors outside the oyster farms, such as rafting of carrier hosts in oceanic currents, commercial or recreational shipping and uncooked seafood translocations (69), are more likely than not to be the source of emergence. This could also explain why regional biosecurity has not prevented disease spread at the continental scale (69). However, the swift application of quarantine and stringent movement controls did appear to prevent or at least slow the local spread of OsHV-1 in Australia, in contrast to the other countries covered in this review. 


\section{Epidemiological research and husbandry modifications}

Research and development do not seem to have made a large impact on farming practices generally, except perhaps in hatcheries where specific treatments of incoming seawater and disinfection enable ongoing production in the face of contamination of water sources $(75,82)$. Verified husbandry modifications have been adopted by farmers in Spain (36) but, apparently, not generally elsewhere, despite epidemiological data from risk factor, intervention and observational studies to support changes to farming methods to reduce economic losses $(17,36,44,83,84,85)$. It is unclear whether this is because of economic factors, such as a lack of capacity for investment in new infrastructure; reluctance to change traditional practices, poor extension of research findings, or a preoccupation with the promise of breeding programmes in some countries.

\section{Genetics research and breeding programmes}

Objective data on OsHV-1 resistance from large-scale, on-farm trials of commercially available, genetically selected oysters are lacking worldwide, even though breeding programmes have been in place for almost a decade. Nonetheless, there are encouraging results from research trials $(8,86)$. In France, the work on OsHV-1 resistance has been mainly experimental. It was shown that the resistance of Pacific oysters to summer mortality associated with the OsHV-1 reference strain is also effective for OsHV-1 $\mu$ Var (87). In 2009, field mortality rates in oysters derived from selected families were $5 \%$ in resistant oysters and 94\% in susceptible oysters (87). In 2009, mass selection experiments were launched and, over the first four generations of selection, gains in survival were 22\%, $44 \%, 50 \%$ and $62 \%$, respectively (86). The genotype $\times$ environment interaction $(G \times E)$ is important for selection and the results indicated that selection to increase OsHV-1 resistance should work across wide areas where the disease is enzootic (8). Few results have been published from private hatcheries or the $\mathrm{CNC}$, which has its own selection programmes in France. However, data from a French breeding programme, 'Plan de Sauvegarde', have been published recently for the period from 2011 to 2014, suggesting that commercial gains have been made in the absence of the pathogen Vibrio aesturianus (88). By 2019, reports from the French industry also suggested progress in achieving survival of commercial spat through selective breeding $(89,90)$. It seems that breeding oysters for higher resistance to one disease does not confer either higher resistance or greater susceptibility to another disease (8). That there could be inadvertent effects on other commercial traits, and trade-offs between resistance to the virus and other traits, is an area that requires further investigation (84).
In Australia and New Zealand, results from research trials showed higher levels of resistance in selected oysters, but there is still room for improvement $(57,62)$. In Australia, the mortality of selected spat is still high and recently it has been seen as a priority to assess the resistance of spat aged two to three months (91). Information in the public domain, from the commercial entity ASI, is that $80 \%$ resistance in one-year-old stock has been achieved in Australia (62). Obtaining resistance in the smaller, younger oysters that are generally purchased from hatcheries by farmers remains a national need in Australia, unless farmers adopt the alternative strategy of overstocking spat, allowing susceptible oysters to die and cultivating the survivors. Most farmers accepted the long-standing advice from proponents of breeding programmes that resistant oysters would become available, which may have led to a lack of interest in or uptake of integrated husbandry approaches to reduce disease losses.

\section{Preparation and response of farmers and industrial resilience}

In both hemispheres, it was reported that there was a lack of cohesion among oyster farmers who, when faced with an emergency, acted individually before thinking collectively (34). Farmers focused on protecting their businesses, resulting in private initiatives (67). In Spain, before 2007, the shellfish industry in Catalonia was fragmented and organised under small historical associations, with little interaction and no common strategy. In the context of mass mortality events of mussels and oysters, the Department of Fisheries promoted the creation of a unique association (FEPROMODEL) to improve communication through better administration, access to public funding and negotiation with intermediaries.

In New Zealand, the industry was unstructured and there was no industry plan of action to address disease outbreaks $(40,41)$. There were too few farmers in the Georges River estuary in Australia to respond collectively or effectively to OsHV-1, and the arrival of OsHV-1 in the Hawkesbury River caused an otherwise well-organised and united Oyster Farmers' Association to collapse, as there were too few viable member businesses to continue. Initially uncoordinated, the Tasmanian and South Australian industries learned from the New South Wales outbreak experience and reacted quickly to prepare for and respond to mortality events, which may have resulted in rapid, supportive responses from government.

An unexpected feature of the emergence in Australia of a disease that affected only one of the two dominant species of farmed oyster, C. gigas, was an element of disunity among the industry. There were potential economic benefits for farmers of the alternative species, the Sydney rock oyster (S. glomerata), which was unaffected by OsHV-1. These 
farmers may have stood to gain through increased market prices and restrictions on the movement of $C$. gigas spat, and their views probably influenced biosecurity policies, leading to what were perceived by $C$. gigas farmers to be overly restrictive requirements for the importation of C. gigas spat from hatcheries in Tasmania.

A dominant feature of the OsHV-1 experience in Europe, ten years after the emergence of highly virulent OsHV- $1 \mu \mathrm{Var}$, is the resilience of the industry. It has restructured, forced by economic circumstances into new business models, based on varying combinations of the following factors in different countries: the consolidation of operations into fewer larger farms and an acceptance of higher mortality, compensated for by heavier stocking of spat, diversification of risk, enhanced marketing and professionalism, and higher prices paid by consumers.

Similarly, in New Zealand, there has been adaptation through consolidation and a market response in the form of higher prices for table oysters. In contrast, in Australia, the industry is still in economic shock, seeking new approaches and not yet stable nine years after the emergence of OsHV-1. In most countries, oyster farmers in those areas that remain free of the virus have nevertheless been impacted, as the availability of OsHV-1-free stock has decreased.

\section{Conclusion}

The mass mortality events that have occurred in C. gigas since 2008 associated with microvariant strains of OsHV-1 have severely disrupted all tiers of the oyster industry in many countries in Europe, as well as in New Zealand and Australia. So far, the industry's responses to these events have been largely economic, with low reliance on technical solutions. Ten years after disease emergence, the industry has consolidated into fewer, larger companies, with the displacement of small farming enterprises. The societal impact has been felt in regional coastal communities, particularly through a loss of employment opportunities and the flow-on effect that this has on local economies. Rather than technical solutions, tolerance of high mortality in the spat's early stages of life and compensating for this by simply placing more spat to grow on farms, in addition to higher market prices for table oysters and an increase in direct marketing, appear to have enabled those farmers who remained in business to stay profitable.

Biosecurity policies and responses to outbreaks, including those of the industry itself, have adversely affected hatcheries and farmers in areas free of disease, mainly through restrictions on animal movements, which lead to a lack of stock to grow. Furthermore, stringent border biosecurity policies have not prevented disease emergence in
New Zealand and Australia. The spread of disease is often viewed as a management failure; however, there are still gaps in our knowledge about OsHV-1 (84). Transmission mechanisms and some pathways may not have been identified or well managed and this could explain the worldwide spread of OsHV-1 (69). For example, the specific role and contribution of recreational and commercial vessels in virus transmission via biofouling and ballast water, oceanic dispersal in currents (including in rafting carrier hosts), and the transfer of virus in uncooked seafood still require further investigation $(59,69,92,93)$.

There may be opportunities for better coordination of industry and government responses to epizootic disease emergence in aquaculture. There is certainly a need for the increased adoption of technical advances once they have been adequately verified.

Bivalves are hedonic foods that contain compounds that can be beneficial for human health (proteins, essential amino acids, long-chain polyunsaturated fatty acids, carotenoids, vitamins and minerals) $(94,95)$, and have been consumed by humans since the Stone Age (5). Mollusc production accounts for $21 \%$ of all aquatic animal production (6) but the consumption of oysters would contribute a smaller percentage to the global human protein intake. Food security can be defined as: 'meeting the needs and preferences of consumers and ensuring that food is affordable for all' (2), and so OsHV- 1 in $C$. gigas does not pose a threat to food security in wealthy countries. However, it is important to note that OsHV-1 variants and mass mortality also occur in other shellfish, including the blood ark shell (Scapharca broughtonii) and scallop (Chlamys farreri) in China, where aquaculture production is increasing exponentially $(96,97$, $98,99,100)$.

Ostreid herpesvirus 1 in $C$. gigas provides an illustration of the significant, widespread and long-lasting disruption to industrial-scale food production that can occur in aquaculture as a result of disease. In this respect, aquaculture is similar to intensive terrestrial animal production, with its centralised production of seed, extensive animal movements and distributed high-density grow-out, all of which create vulnerabilities and make preparation and planning for responses to infectious diseases imperative. 


\title{
L'impact des microvariants du virus herpétique ostreid herpesvirus 1 sur la culture d'huîtres creuses dans les hémisphères Nord et Sud depuis 2008
}

\author{
M. Fuhrmann, A. Castinel, D. Cheslett, D. Furones Nozal \\ \& R.J. Whittington
}

\section{Résumé}

L'élevage de mollusques occupe le troisième rang mondial parmi les activités de l'aquaculture en termes de production ; l'une des principales espèces élevées est l'huître creuse (Crassostrea gigas). Depuis 2008, la rentabilité des élevages de C. gigasen Europe, en Nouvelle-Zélande eten Australie a étéfortementcompromise par une mortalité massive due à des microvariants du virus herpétique Ostreid herpesvirus 1. Dix ans après l'émergence de cette maladie, on observe une forte concentration du secteur autour d'entreprises moins nombreuses mais de plus grande envergure qui ont remplacé l'ancien tissu d'exploitations artisanales et occasionné un déclin de l'emploi dans les communautés littorales. Au lieu de rechercher des solutions techniques, le secteur a eu recours à des stratégies de compensation axées sur la production, par exemple en augmentant le nombre de naissains mis en place dans les fermes, en augmentant le prix des huîtres de consommation ou en développant la vente directe, stratégies dont l'impact sur la rentabilité semble avoir été positif. En revanche, les mesures de biosécurité mises en place et les réponses apportées aux foyers, y compris celles introduites par le secteur lui-même ont eu des conséquences imprévues pour les écloseries et les éleveurs des zones indemnes de maladie, principalement en raison des restrictions imposées aux transferts d'animaux, sans pour autant prévenir la propagation de la maladie à l'échelle mondiale. Une meilleure coordination des réponses sectorielles et publiques face à l'émergence des maladies épizootiques affectant l'aquaculture devrait être possible. II sera également indispensable de recourir davantage aux avancées techniques mises au point par la recherche dès que ces solutions auront été dûment validées.

\section{Mots-clés}

Coquillages - Crassostrea gigas - Herpèsvirus - Huîtres - Impact sociétal - Mollusques - Mortalité - Ostreid herpesvirus 1-Réponse des pouvoirs publics - Résilience - Secteur de l'aquaculture.

\section{Impacto de microvariantes del herpesvirus de los ostreidos 1 en el cultivo de ostra japonesa en los hemisferios Norte y Sur desde 2008}

\author{
M. Fuhrmann, A. Castinel, D. Cheslett, D. Furones Nozal \\ \& R.J. Whittington
}

\section{Resumen}

La producción de moluscos es la tercera actividad acuícola más productiva del mundo, y la ostra japonesa (o del Pacífico) (Crassostrea gigas) ocupa un lugar destacado entre las principales especies cultivadas. Desde 2008, la viabilidad de esta industria en Europa, Nueva Zelanda y Australia está amenazada por episodios de mortandad masiva de $C$. gigas causados por microvariantes del herpesvirus 
de los ostreidos 1 (ostreid herpesvirus 1). Diez años después de la aparición de la enfermedad, lo que se observa es que la industria se ha ido concentrando en unas pocas empresas de grandes dimensiones, que han desplazado a las pequeñas empresas ostrícolas y causado la pérdida de numerosos empleos en las comunidades costeras. En lugar de buscar soluciones técnicas, la industria ha optado más bien por estrategias de producción compensatorias (como aumentar el número de semillas de ostra por explotación, subir los precios de mercado de las ostras de mesa o recurrir a la comercialización directa) que parecen haber deparado rentabilidad. Las políticas de seguridad biológica y la respuesta a los brotes, incluida la del propio sector, han tenido consecuencias imprevistas para los viveros y acuicultores situados en zonas libres de la enfermedad, debido sobre todo a las restricciones impuestas a los desplazamientos de animales, sin que ello haya servido para impedir la diseminación mundial de esta patología. Puede haber margen para coordinar más eficazmente las respectivas respuestas de la industria y de los poderes públicos ante la aparición de enfermedades epizoóticas en la acuicultura. Lo que sin ninguna duda es necesario es incorporar en mayor medida los adelantos técnicos resultantes de la investigación, una vez contrastada debidamente cada solución.

\section{Palabras clave}

Crassostrea gigas - Herpesvirus - Ostreid herpesvirus 1 - Impacto en la sociedad Marisco - Moluscos - Mortalidad - Ostras - Resiliencia - Respuesta de los poderes públicos - Sector de la acuicultura.

\section{References}

1. High Level Panel of Experts on Food Security and Nutrition (2014). - Sustainable fisheries and aquaculture for food security and nutrition. Committee on World Food Security, Food and Agriculture Organization of the United Nations, Rome, Italy. Available at: www.fao.org/fileadmin/user upload/hlpe/hlpe_documents/HLPE_S_and_R/HLPE_2014_ Sustainable_Fisheries_and_Aquaculture_Summary_EN.pdf (accessed on 15 January 2019).

2. Jennings S., Stentiford G.D. [...] \& Verner-Jeffreys D.W. (2016). - Aquatic food security: insights into challenges and solutions from an analysis of interactions between fisheries, aquaculture, food safety, human health, fish and human welfare, economy and environment. Fish and Fisheries, 17 (4), 893-938. doi:10.1111/faf.12152.

3. Sumner C.E. (1972). - Oysters and Tasmania. Tas. Fish. Res., $6(2), 1-18$.

4. Lubofsky E. (2018). - In the Chesapeake Bay, shell mounds show a long history of sustainable oyster harvests. Hakai Magazine, 22 November. Available at: www. hakaimagazine.com/news/in-the-chesapeake-bay-shellmounds-show-a-long-history-of-sustainable-oyster-harvests/ (accessed on 15 January 2019).

5. Clarke J. (2013). - Oysterman: the world's biggest oyster farm. J. Clarke, Fingal Bay, New South Wales, Australia, 184 pp.
6. Food and Agriculture Organization of the United Nations (FAO) (2018). - The state of world fisheries and aquaculture 2018 - meeting the Sustainable Development Goals. FAO, Rome, Italy. Available at: www.fao.org/3/i9540en/I9540EN. pdf (accessed on 15 January 2019).

7. Renault T. (2009). - Trends and perspectives in preventing and controlling infectious diseases in molluscs. In Aquaculture research progress (T.T. Nakamura, ed.). Nova Science Publishers, Hauppauge, New York, 99-126.

8. Dégremont L., Garcia C. \& Allen S.K. (2015). - Genetic improvement for disease resistance in oysters: a review. J. Invertebr. Pathol., 131, 226-241. doi:10.1016/j.jip. 2015.05.010.

9. Segarra A., Pépin J.F., Arzul I., Morga B., Faury N. \& Renault T. (2010). - Detection and description of a particular Ostreid herpesvirus 1 genotype associated with massive mortality outbreaks of Pacific oysters, Crassostrea gigas, in France in 2008. Virus Res., 153 (1), 92-99. doi:10.1016/j. virusres.2010.07.011.

10. European Food Safety Authority (EFSA) Panel on Animal Health and Welfare (2015). - Scientific opinion on oyster mortality. EFSA J., 13 (6), 4122, 59 pp. doi:10.2903/j. efsa.2015.4122. 
11. World Organisation for Animal Health (OIE) (2018). - Chapter 2.4.5. Infection with ostreid herpesvirus 1 microvariants. In Manual of Diagnostic Tests for Aquatic Animals. OIE, Paris, France. Available at: www.oie.int/ index.php?id=2439\&L=0\&htmfile=chapitre_ostreid_ herpesvirus_1.htm (accessed on 20 May 2019).

12. Miossec L., Allain G., Arzul I., Francois C., Garcia C. \& Cameron A. (2009). - First results of an epidemiological study on oyster (Crassostrea gigas) mortality events in France during summer 2008. In ISVEE 12: Proceedings of the 12th Symposium of the International Society for Veterinary Epidemiology and Economics, Durban, South Africa, 10-14 August, 228. Available at: www.sciquest.org.nz/ elibrary/edition/5247 (accessed on 15 May 2019).

13. Pernet F., Barret J., Marty C., Moal J., Le Gall P. \& Boudry P. (2010). - Environmental anomalies, energetic reserves and fatty acid modifications in oysters coincide with an exceptional mortality event. Mar. Ecol. Progr. Series, 401, 129-146. doi:10.3354/Meps08407.

14. Dundon W.G., Arzul I., Omnes E., Robert M., Magnabosco C., Zambon M., Gennari L., Toffan A., Terregino C., Capua I. \& Arcangeli G. (2011). - Detection of Type 1 Ostreid Herpes variant (OsHV-1 $\mu v a r$ ) with no associated mortality in French-origin Pacific cupped oyster Crassostrea gigas farmed in Italy. Aquaculture, 314 (1-4), 49-52. doi:10.1016/j.aquaculture.2011.02.005.

15. Lynch S.A., Carlsson J. \& Culloty S.C. (2011). - Investigation into the involvement of Ostreid Herpes virus 1 (OsHV-1) in summer mortalities of Pacific oyster, Crassostrea gigas, spat and market sized adults in Ireland. J. Shellfish Res., 30 (2), 528-529.

16. Schikorski D., Renault T., Saulnier D., Faury N., Moreau P. \& Pépin J.F. (2011). - Experimental infection of Pacific oyster Crassostrea gigas spat by Ostreid herpesvirus 1: demonstration of oyster spat susceptibility. Vet Res., 42, 27. doi:10.1186/12979716-42-27.

17. Peeler E.J., Reese R.A., Cheslett D.L., Geoghegan F., Power A. \& Thrush M.A. (2012). - Investigation of mortality in Pacific oysters associated with ostreid herpesvirus-1 $\mu$ Var in the Republic of Ireland in 2009. Prev. Vet. Med., 105 (1-2), 136-143. doi:10.1016/j.prevetmed.2012.02.001.

18. Pernet F., Barret J., Le Gall P., Corporeau C., Dégremont L., Lagarde F., Pépin J.-F. \& Keck N. (2012). - Mass mortalities of Pacific oysters Crassostrea gigas reflect infectious diseases and vary with farming practices in the Mediterranean Thau lagoon, France. Aquacult. Environ. Interactions, 2 (3), 215-237. doi:10.3354/aei00041.

19. Roque A., Carrasco N., Andree K.B., Lacuesta B., Elandaloussi L., Gairin I., Rodgers C.J. \& Furones M.D. (2012). - First report of OsHV-1 microvar in Pacific oyster (Crassostrea gigas) cultured in Spain. Aquaculture, 324-325, 303-306. doi:10.1016/j. aquaculture.2011.10.018.
20. Gittenberger A., Voorbergen-Laarman M.A. \& Engelsma M.Y. (2016). - Ostreid herpesvirus OsHV-1 muVar in Pacific oysters Crassostrea gigas (Thunberg 1793) of the Wadden Sea, a UNESCO world heritage site. J. Fish Dis., 39 (1), 105-109. doi:10.1111/jfd.12332.

21. Mortensen S., Strand A., Bodvin T., Alfjorden A., Skar C.K., Jelmert A., Aspan A., Saelemyr L., Naustvoll L.J. \& Albretsen J. (2016). - Summer mortalities and detection of ostreid herpesvirus microvariant in Pacific oyster Crassostrea gigas in Sweden and Norway. Dis. Aquat. Organisms, 117 (3), 171-176. doi:10.3354/dao02944.

22. Keeling S., Brosnahan C., Williams R., Gias E., Hannah M., Bueno R., McDonald W. \& Johnston C. (2014). - New Zealand juvenile oyster mortality associated with Ostreid herpesvirus 1 - an opportunistic longitudinal study. Dis. Aquat. Organisms, 109 (3), 231-239. doi:10.3354/dao02735.

23. Jenkins C., Hick P., Gabor M., Spiers Z., Fell S.A., Gu X., Read A., Go J., Dove M., O'Connor W., Kirkland P.D. \& Frances J. (2013). - Identification and characterisation of an ostreid herpesvirus-1 microvariant (OsHV-1 micro-var) in Crassostrea gigas (Pacific oysters) in Australia. Dis. Aquat. Organisms, 105 (2), 109-126. doi:10.3354/dao02623.

24. Le Bihan V., Morineau B. \& Ollivier P. (2017). - Recensements de la conchyliculture 2001-2012 : Résultats et analyses, Direction des Pêches Maritimes et de l'Aquaculture et le Laboratoire d'Économie et de Management de Nantes Atlantique de l'Université de Nantes, France, 117 pp. Available at: http://agriculture.gouv.fr/telecharger /86410? token=b55756d5329858754bf64b35253f5a15 (accessed on 15 January 2019).

25. Lupo C., Ezanno P., Arzul I., Garcia C., Jadot C., Joly J.P., Renault T. \& Bareille N. (2016). - How network analysis of oyster movements can improve surveillance and control programs of infectious diseases. In Proc. Conference: AquaEpi I, 20-22 September, Oslo, Norway. Front. Vet. Sci., 44. doi:10.3389/conf.FVETS.2016.02.00044.

26. Guillotreau P., Le Bihan J., Le Bihan V., Pardo S. \& Ollivier P. (2016). - Programme ANR «GIGASSAT» Adaptation des écosystèmes ostréicoles au changement global : perception et adaptation des ostréiculteurs face aux changements globaux. Available at: www. gigassat.org/content/download/95052/file/Synthese\% 20pro\%202016-01-12_V.d\%C3\%A9finitive.pdf (accessed on 15 February 2019)

27. Bord Iascaigh Mhara (BIM) [Sea Fisheries Board (Ireland)] (2018). - BIM annual aquaculture survey. BIM, Dun Laoghaire, County Dublin, Ireland, 16 pp. Available at: www.bim.ie/ media/bim/content/publications/aquaculture/BIM-AnnualAquaculture-Survey-2018.pdf (accessed on 15 February 2019).

28. Asociación Empresarial de Acuicultura de España (APROMAR) [Business Association of Spanish Marine Aquaculture Producers] (2018). - La acuicultura en España. Informe APROMAR. APROMAR, Chiclana, Cádiz, Spain, 94 pp. Available at: www.apromar.es/sites/default/files/2018/ APROMAR_Informe_ACUICULTURA_2018.pdf (accessed on 15 January 2019). 
29. Pérez L., García R., García R. \& Virgilio J. (2014). - Pesca y acuicultura en Tarragona. Estudio del Mercado Laboral, Asturias, Spain, 63 pp. Available at: www.mapama.gob. es/app/jacumar/recursos_informacion/Documentos/ Publicaciones/301_Presentacion_Estudio.pdf (accessed on 15 February 2019).

30. Aquaculture New Zealand (2018). - Aquaculture New Zealand: a sector overview with key facts and statistics. Aquaculture New Zealand, Nelson, New Zealand, 24 pp. Available at: www.aquaculture.org.nz/wp-content/uploads/2018/08/NewZealand-Aquaculture-facts-2018.pdf (accessed on 15 May 2019).

31. Davis J. (2016). - A national industry response to Pacific oyster mortality syndrome (POMS). Oysters Australia Ltd \& Fisheries Research and Development Corporation, Canberra, Australian Capital Territory, Australia, 40 pp. Available at: www.frdc.com.au/Archived-Reports/FRDC\%20Projects/2015406-DLD.pdf (accessed on 15 May 2019).

32. Australian Bureau of Agricultural and Resource Economics and Sciences (ABARES) (2016). - Australian fisheries and aquaculture statistics 2016. ABARES, Canberra, Australian Capital Territory, Australia. Available at: www.agriculture.gov. au/abares/research-topics/fisheries/fisheries-data\#australianfisheries-and-aquaculture-statistics-2016 (accessed on 20 July 2018)

33. Rockliff J. (2016). - \$7.6m in state government support for oyster farmers. Fisheries Research and Development Corporation, Canberra, Australian Capital Territory, Australia. Available at: www.premier.tas.gov.au/releases/\$7.6m_in_ state_government_support_for_oyster_farmers (accessed on 16 July 2018).

34. Guillotreau P., Le Bihan V. \& Pardo S. (2017). - Mass mortality of farmed oysters in France: bad responses and good results. In Global change in marine systems - societal and governing responses. Routledge, Abingdon-on-Thames, United Kingdom, 348 pp. doi:10.4324/9781315163765.

35. Morrissey T., McCleary S., Collins E., Henshilwood K. \& Cheslett D. (2015). - An investigation of ostreid herpes virus microvariants found in Crassostrea gigas oyster producing bays in Ireland. Aquaculture, 442, 86-92. doi:10.1016/j. aquaculture.2015.02.026.

36. Carrasco N., Gairin I., Pérez J., Andree K.B., Roque A., Fernández-Tejedor M., Rodgers C.J., Aguilera C. \& Furones M.D. (2017). - A production calendar based on water temperature, spat size, and husbandry practices reduce OsHV-1 uvar impact on cultured Pacific oyster Crassostrea gigas in the Ebro Delta (Catalonia), Mediterranean coast of Spain. Front. Physiol., 8, 125. doi:10.3389/fphys.2017.00125.

37. Abollo E., Villalba A., Sieiro P. \& Maroto J. (2017). - El cultivo de la ostra rizada en Galicia - pasado, presente y futuro. Centro Tecnológico del Mar - Fundación CETMAR; Centro de Investigacións Mariñas, Conselleria del Mar, Xunta de Galicia, Vigo (Pontevedra), Spain.
38. Hay B., Jessop C. \& Jessop B. (2012). - A preliminary study of patterns of Pacific oyster mortality in New Zealand: clues and qs in the management of Ostreid herpesvirus. In Shellfish Safety Workshop. New Zealand Seafood Standards Council, Wellington, New Zealand, 55 pp. Available at: www. nzssc.co.nz/f2 186,107975/107975_BH_CBJ_Technical_ Workshop_presentation_v2.pdf (accessed on 15 February 2019)

39. Bingham P., Brangenberg N., Williams R. \& van Andel M. (2013). - Investigation into the first diagnosis of Ostreid herpesvirus type 1 in Pacific oysters. Surveillance (Wellington), 40 (2), 20-24. Available at: www.researchgate. net/publication/263966667_Investigation_into_the_first_ diagnosis_of_ostreid_herpesvirus_type_1_in_Pacific_oysters (accessed on 5 July 2019).

40. Castinel A., Fletcher L., Dhand N., Rubio A., Whittington R.J. $\&$ Taylor M. (2015). - OsHV-1 mortalities in Pacific oysters in Australia and New Zealand: the farmer's story. Cawthron Report No. 2567. Cawthron Institute, Nelson, New Zealand, 69 pp. Available at: www.cawthron.org.nz/media_new/ publications/pdf/2015_09/CR2567printable.pdf (accessed on 15 February 2019).

41. Coast \& Catchment Ltd, Environmental Consultants (2016). - Managing biosecurity risk for business benefit: aquaculture biosecurity practices research. MPI Technical Paper No. 2016/14. Ministry for Primary Industries (MPI), Wellington, New Zealand, 217 pp. Available at: www.mpi. govt.nz/dmsdocument/11743/send (accessed on 17 May 2019).

42. Bingham P. (2016). - Marine and freshwater quarterly report of investigations of suspected exotic marine and freshwater pests and diseases. Surveillance (Wellington), 43 (1), 25-27. Available at: www.sciquest.org.nz/node/115607 (accessed on 5 July 2019)

43. Paul-Pont I., Evans O., Dhand N.K., Rubio A., Coad P. \& Whittington R.J. (2014). - Descriptive epidemiology of mass mortality due to Ostreid herpesvirus-1 (OsHV-1) in commercially farmed Pacific oysters (Crassostrea gigas) in the Hawkesbury River estuary, Australia. Aquaculture, 422-423, 146-159. doi:10.1016/j.aquaculture.2013.12.009.

44. de Kantzow M.C., Hick P.M., Dhand N.K. \& Whittington R.J. (2017). - Risk factors for mortality during the first occurrence of Pacific oyster mortality syndrome due to Ostreid herpesvirus-1 in Tasmania, 2016. Aquaculture, 468 (1), 328-336. doi:10.1016/j.aquaculture.2016.10.025.

45. Primary Industries and Regions South Australia (PIRSA) (2018). - Port River POMS outbreak in feral oysters. PIRSA, Adelaide, South Australia, Australia. Available at: www.pir. sa.gov.au/aquaculture/aquatic_animal_health/pacific_oyster_ mortality_syndrome/port_river_outbreak_2018_feral_oysters (accessed on 11 September 2018).

46. Agreste (2014). - Agreste Cahiers conchyliculture n³16 - Recensement de la conchyliculture 2012. Juillet 2014. Available at: www.agreste.agriculture.gouv.fr/IMG/pdf/ primeur316.pdf (accessed on 15 February 2019). 
47. Aquaculture New Zealand (2010). - New Zealand aquaculture - farm facts, 3rd Ed. Aquaculture New Zealand, Nelson, New Zealand, 22 pp. Available at: www.parliament.nz/ resource/0000149427 (accessed on 15 January 2019).

48. Department of Primary Industries (DPI) (New South Wales) (2019). - Aquaculture production reports. DPI, Orange, New South Wales, Australia. Available at: www.dpi.nsw.gov. au/fishing/aquaculture/publications/aquaculture-productionreports (accessed on 13 February 2019).

49. Australian Broadcasting Corporation (ABC) Rural Reporters (2017). - Oyster shortage for Christmas as demand outstrips supply and prices soar. ABC, Sydney, New South Wales, Australia. Available at: www.abc.net.au/ news/rural/2017-10-10/looming-oyster-shortage/9030562 (accessed on 15 February 2019).

50. European Commission (2009). - Aide d'Etat n NN 22/2009 - France: Mesures de soutien accordées aux entreprises ostréicoles touchées par la mortalité des huîtres et naissains d'huîtres durant l'été 2008. Available at: http://ec.europa.eu/ competition/state_aid/cases/231020/231020_997183_4_2. pdf (accessed on 15 February 2019).

51. Whetstone T. (2018). - Marshall Government moves to protect oyster industry. Office of Steven Marshall, Premier of South Australia, 3 July, Adelaide, South Australia, Australia. Available at: https://premier.sa.gov. $\mathrm{au} / \mathrm{news}$ /marshall-government-moves-to-protectoyster-industry (accessed on 17 February 2019).

52. Community Research and Development Information Service (CORDIS), European Commission (2019). - VIVALDI: Horizon 2020: preventing and mitigating farmed bivalve diseases. CORDIS, Luxembourg. Available at: https:// cordis.europa.eu/project/rcn/200215/factsheet/en (accessed on 7 February 2019).

53. Community Research and Development Information Service (CORDIS), European Commission (2019). - Controlling infectious diseases in oysters and mussels in Europe. Factsheet. CORDIS, Luxembourg. Available at: https://cordis.europa. eu/project/rcn/97708/factsheet/en (accessed on 7 February 2019).

54. Guillotreau P., Allison E.H., Bundy A., Cooley S.R., Defeo O., Le Bihan V., Pardo S., Perry R.I., Santopietro G. \& Seki T. (2017). - A comparative appraisal of the resilience of marine social-ecological systems to mass mortalities of bivalves. Ecol. Soc., 22 (1), 46. doi:10.5751/ES-09084-220146.

55. Clegg T.A., Morrissey T., Geoghegan F., Martin S.W., Lyons K., Ashe S. \& More S.J. (2014). - Risk factors associated with increased mortality of farmed Pacific oysters in Ireland during 2011. Prev. Vet. Med., 113 (2), 257-267. doi:10.1016/j. prevetmed.2013.10.023.

56. Holland J. (2012). - New Zealand oyster farmers eye recovery. SeafoodSource, 29 June. Available at: www.seafoodsource.com/ features/new-zealand-oyster-farmers-eye-recovery (accessed on 15 February 2019).
57. Symonds J.E., King N. \& Buxton P. (2018). - New Zealand aquaculture selective breeding: from theory to industry application for three flagship species. In Proc. World Congress on Genetics Applied to Livestock Production, Vol.: Aquaculture, 12-16 February, Auckland, New Zealand, 1035. Available at: www.wcgalp.org/proceedings/2018 (accessed on 20 May 2019).

58. Anon. (2013). - News in brief: investing in innovation. Aquacult. N.Z., October, 2. Available at: www.aquaculture. org.nz/wp-content/uploads/2013/11/Spreads_ANZOctober-2013.pdf (accessed on 17 February 2019).

59. Anon. (2011). - Final report: International OsHV-1 $\mu$ Var Workshop, Cairns, Queensland, Australia, 9-10 July. Fisheries Research and Development Corporation, Canberra, Australian Capital Territory, Australia. Available at: www. eurl-mollusc.eu/content/download/52616/file/OYSTER\% 20 HERPES \% 20VIRUS\% 20 WORKSHOP\%2 Ofinal $\% 20$ REPORT.pdf (accessed on 20 May 2019).

60. Zippel B., Moxham R., Calvert J., Cameron A. \& Lewis T. (2012). - Understanding and planning for the potential impacts of OsHVl $\mu$ var on the Australian Pacific oyster industry (FRDC 2011/043) - French study tour report. In Understanding and planning for the potential impacts of OsHV-1 $\mu$ Var on the Australian Pacific oyster industry (FRDC 2011/043) - final report (T. Lewis, D. Defenderfer \& B. Zippel, eds). RDS Partners Pty Ltd, Hobart, Tasmania, Australia, 179 pp.

61. Australian Seafood Industry (ASI) (2017). - Australian Seafood Industry Pty Ltd - annual report year ending June 2017. ASI, Hobart, Tasmania, Australia. Available at: www.asioysters. com.au/uploads/2/5/9/7/25976125/asi_annual_report_ 2017-final_-_2017-10-12_circulated_____pdf (accessed on 15 January 2019).

62. Australian Seafood Industry (ASI) (2018). - ASI thoroughbred oysters - breeding program. ASI, Hobart, Tasmania, Australia. Available at: www.asioysters.com.au/breeding-program.html (accessed on 30 November 2018).

63. Australian Government (2017). - Cooperative Research Centres (CRC) Program: CRC Projects selection round outcomes. Available at: www.business.gov.au/Assistance/ Cooperative-Research-Centres-Programme/CooperativeResearch-Centres-Projects-CRC-Ps/Current-CRC-P-selectionround\#crcpl (accessed on 10 August 2018).

64. European Council (EC) (1988). - Council Directive 2006/88/ EC of 24 October 2006 on animal health requirements for aquaculture animals and products thereof, and on the prevention and control of certain diseases in aquatic animals. Off. J. Eur. Communities, L 328, 24.11.2006, 14-56. Available at: https://eur-lex.europa.eu/legal-content/EN/ ALL/?uri=CELEX:32006L0088 (accessed on 20 May 2019).

65. European Commission (EC) (2010). - Commission Regulation (EU) No 175/2010 of 2 March 2010 implementing Council Directive 2006/88/EC as regards measures to control increased mortality in oysters of the species Crassostrea gigas in connection with the detection of ostreid herpesvirus 1 uvar (OsHV-1 uvar). (Text with EEA relevance.) Off. J. Eur. Union, L 52, 3.3.2010, 1-13. Available at: https://eur-lex.europa. eu/legal-content/EN/ALL/?uri=CELEX\%3A32010R0175 (accessed on 20 May 2019). 
66. European Commission (EC) (2011). - Commission Decision 2011/187/EU: Commission Decision of 24 March 2011 amending Decision 2010/221/EU as regards the approval of national measures for preventing the introduction of ostreid herpesvirus 1 uvar (OsHV-1 $\mu v a r$ ) into certain areas of Ireland and the United Kingdom (notified under document C(2011) 1825). Text with EEA relevance. Off. J. Eur. Union, L 80, 26.3.2011, 15-18. Available at: https://eur-lex.europa. eu/legal-content/EN/ALL/?uri=CELEX\%3A32010R0175 (accessed on 20 May 2019).

67. Richez F. (2012). - Report on the impact of recent Crassostrea gigas mortality in France and its consequences to oyster farming in Northern Ireland. Aquaculture Initiative, Downpatrick, Country Down, Northern Ireland, 80 pp. Available at: www.aquacultureinitiative.eu/FINALprinted.pdf (accessed on 20 May 2019)

68. Lupo C., François C., Arzul I., Garcia C., Joly J.-P. \& Renault T. (2012). - Défis de la surveillance des maladies chez les coquillages marins en France. Épidémiol. Santé Anim., 61, 27-42. Available at: http://archimer.ifremer.fr/ doc/00109/22023/19653.pdf (accessed on 15 January 2019).

69. Whittington R.J., Paul-Pont I., Evans O., Hick P. \& Dhand N.K. (2018). - Counting the dead to determine the source and transmission of the marine herpesvirus OsHV-1 in Crassostrea gigas. Vet Res., 49, 34. doi:10.1186/s13567-0180529-7.

70. Herbert B. (2011). - Aquatic animal health. Anim. Hlth Surveillance Q. Rep., 16 (1), 9-10. Available at: www.sciquest. org.nz/elibrary/edition/5531 (accessed on 20 May 2019).

71. Lupo C., Amigo A.O., Mandard Y.V., Peroz C. \& Renault T. (2014). - Improving early detection of exotic or emergent oyster diseases in France: identifying factors associated with shellfish farmer reporting behaviour of oyster mortality. Prev. Vet. Med., 116 (1-2), 168-182. doi:10.1016/j.prevetmed.2014.05.002.

72. Department of Primary Industries (DPI), New South Wales Government (2019). - Reporting aquatic pests and diseases. DPI, Orange, New South Wales, Australia. Available at: www. dpi.nsw.gov.au/fishing/pests-diseases/reporting (accessed on 30 November 2018)

73. Primary Industries and Regions South Australia (PIRSA) (2018). - Pacific oyster mortality syndrome (POMS). PIRSA, Adelaide, South Australia, Australia. Available at: www.pir. sa.gov.au/aquaculture/aquatic_animal_health/pacific_oyster_ mortality_syndrome (accessed on 30 November 2018).

74. Biosecurity Australia, Tasmanian Government (2018). - Pacific Oyster Mortality Syndrome (POMS). Department of Primary Industries, Parks, Water \& Environment, Hobart, Tasmania, Australia. Available at: https://dpipwe.tas.gov.au/biosecuritytasmania/aquatic-pests-and-diseases/aquatic-biosecuritythreats/poms\#ReportingofMortalitiesinAquaticAnimals (accessed on 30 November 2018).

75. Hick P., Evans O., Looi R., English C. \& Whittington R.J. (2016). - Stability of Ostreid herpesvirus-1 (OsHV-1) and assessment of disinfection of seawater and oyster tissues using a bioassay. Aquaculture, 450, 412-421. doi:10.1016/j. aquaculture.2015.08.025.
76. Le Bihan V., Catalo M. \& Le Bihan J. (2018). - Reorganization of the value chain activities of oyster companies on the Atlantic coast following health crises in France (2006-2013). Mar. Pol. doi:10.1016/j.marpol.2018.05.013

77. Ugalde S.C., Preston J., Ogier E. \& Crawford C. (2018). Analysis of farm management strategies following herpesvirus (OsHV-1) disease outbreaks in Pacific oysters in Tasmania, Australia. Aquaculture, 495, 179-186. doi:10.1016/j. aquaculture.2018.05.019.

78. France 24 (2018). - Down to Earth: oysters are dying: who's the culprit? Available at: www.france24.com/en/20181207down-earth-oyster-mortalities-herpes-virus-brittany-franceresistant-genetic-selection (accessed on 17 February 2019).

79. Giorgetti A. \& Butcher G. (2010). - The Northland regional economic impacts of aquaculture. Enveco, Hamilton East, New Zealand, 47 pp. Available at: www.nrc.govt.nz/media/10453/ finalreg ionaleconomici mpactsofaquaculturereportbyenveco6. pdf (accessed on 17 February 2019).

80. Crawford C. \& Preston J. (2017). - OSHV-1 (Pacific oyster mortality syndrome) in New Zealand, September 2017. IMAS UTAS, newsletter. POMS Update \# 8, October 2017, 8 pp. Available at: www.imas.utas.edu.au/_data/assets/pdf_ file/0008/1035557/POMS-Newsletter-8-NZ-trip.pdf (accessed on 18 February 2019).

81. Whetstone T. (2019). - SA oyster industry on the road to recovery. Office of Steven Marshall, Premier of South Australia, 3 July, Adelaide, South Australia, Australia. Available at: https://premier.sa.gov.au/news/sa-oyster-industry-on-theroad-to-recovery (accessed on 7 February 2019).

82. Whittington R., Hick P., Evans O., Rubio A., Alford B., Dhand N. \& Paul-Pont I. (2015). - Protection of Pacific oyster (Crassostrea gigas) spat from mortality due to ostreid herpesvirus-1 (OsHV-1 $\mu$ Var) using simple treatments of incoming seawater in land-based upwellers. Aquaculture, 437, 10-20. doi:10.1016/j.aquaculture.2014.11.016.

83. Whittington R., Dhand N., Evans O. \& Paul-Pont I. (2015). Further observations on the influence of husbandry practices on OsHV-1 $\mu$ Var mortality in Pacific oysters Crassostrea gigas: age, cultivation structures and growing height. Aquaculture, 438, 82-97. doi:10.1016/j.aquaculture.2014.12.040.

84. Pernet F., Lupo C., Bacher C. \& Whittington R.J. (2016). - Infectious diseases in oyster aquaculture require a new integrated approach. Philos. Trans. Roy. Soc. Lond., B, Biol. Sci., 371 (1689), pii: 20150213. doi:10.1098/rstb.2015.0213.

85. Rodgers C., Arzul I., Carrasco N. \& Furones Nozal D. (2018). A literature review as an aid to identify strategies for mitigating Ostreid herpesvirus 1 in Crassostrea gigas hatchery and nursery systems. Rev. Aquacult., 1-21. doi:10.1111/raq.12246.

86. Dégremont L., Nourry M. \& Maurouard E. (2015). - Mass selection for survival and resistance to OsHV-1 infection in Crassostrea gigas spat in field conditions: response to selection after four generations. Aquaculture, 446, 111-121. doi:10.1016/j.aquaculture.2015.04.029. 
87. Dégremont L. (2011). - Evidence of herpesvirus (OsHV-1) resistance in juvenile Crassostrea gigas selected for high resistance to the summer mortality phenomenon. Aquaculture, 317 (1-4), 94-98. doi:10.1016/j. aquaculture.2011.04.029.

88. Dégremont L., Maurouard E., Ledu C. \& Benabdelmouna A. (2019). - Synthesis of the 'PLAN DE SAUVEGARDE' using selected all-triploid oysters to reduce the shortage of spat in France due to OsHV-1-associated mortality in Crassostrea gigas. Aquaculture, 505, 462-472. doi:10.17882/59658.

89. Blin J.-L., Laisney N., Lefebvre V., Moal S. \& Petinay S. (2019). - Réseau des Centres Techniques, mortalité des huîtres en Normandie. Bilan 2014-2018. Synergie Mer et Littoral (SMEL), Blainville-sur-Mer, Basse-Normandie, France, 19 pp. Available at: https://protect-au.mimecast.com/s/3IpPCr8DLRtl 6x9RFzoV8M?domain=smel.fr (accessed on 30 May 2019).

90. Glize P. \& Metivier R. (2019). - Suivi de la mortalité de l'huître creuse. Bilan final 2018. Syndicat Mixte pour le Développement de l'Aquaculture et de la Pêche en Pays de la Loire, Nantes, France. Available at: https://protect-au. mimecast.com/s/-iilCq7BKYtjR9WyiZV-Ev?domain=smidap.fr (accessed on 30 May 2019).

91. Australian Seafood Industry (ASI) (2018). - Newsletter, Summer 2019. ASI, Hobart, Tasmania, Australia, 9 pp. Available at: www.asioysters.com.au/uploads/2/5/9/7/25976125/asi_newsletter_ summer2019_v002.pdf (accessed on 17 February 2019).

92. Deveney M., Roberts S., Moody N., Crane M. \& Ellard K. (2017). - Biofouling as a long distance vector for pathogens. In Proceedings of the Fourth Australasian Scientific Conference on Aquatic Animal Health \& Biosecurity (M.S.J. Crane, ed.), 10-14 July, Cairns, Queensland, Australia. Fisheries Research and Development Corporation, Canberra, Australian Capital Territory, Australia, 35 pp.

93. Roberts S., Alleway H., Begg G., Deveney M., Evans J., Holmes L., Ingham G., Li X., Matthews E., McGowan T., Paskin R. \& Sloan S. (2017). - When spat hits the fan: emergency disease response and ongoing recovery in the South Australian oyster aquaculture industry. In Proceedings of the Fourth Australasian Scientific Conference on Aquatic Animal Health \& Biosecurity (M.S.J. Crane, ed.), 10-14 July, Cairns, Queensland, Australia. Fisheries Research and Development Corporation, Canberra, Australian Capital Territory, Australia, $35 \mathrm{pp}$.
94.Aru V., Khakimov B., Sørensen K.M. \& Engelsen S.B. (2018). - The foodome of bivalve molluscs: from hedonic eating to healthy diet. J. Food Compos. Analysis, 69, 13-19. doi:10.1016/j.jfca.2018.01.018.

95. Venugopal V. \& Gopakumar K. (2017). - Shellfish: nutritive value, health benefits, and consumer safety. Compr. Rev. Food Sci. Safety, 16 (6), 1219-1242. doi:10.1111/15414337.12312

96. Xia J., Bai C., Wang C., Song X. \& Huang J. (2015). - Complete genome sequence of Ostreid herpesvirus-1 associated with mortalities of Scapharca broughtonii broodstocks. Virol J., 12, 110. doi:10.1186/s12985-015-0334-0.

97. Xiao J., Ford S.E., Yang H., Zhang G., Zhang F. \& Guo X. (2005). - Studies on mass summer mortality of cultured zhikong scallops (Chlamys farreri Jones et Preston) in China. Aquaculture, 250 (3-4), 602-615. doi:10.1016/j. aquaculture.2005.05.002.

98. Bai C., Gao W., Wang C., Yu T., Zhang T., Qiu Z., Wang Q. \& Huang J. (2016). - Identification and characterization of Ostreid herpesvirus 1 associated with massive mortalities of Scapharca broughtonii broodstocks in China. Dis. Aquat. Organisms, 118 (1), 65-75. doi:10.3354/ dao02958.

99. Bai C., Wang C., Xia J., Sun H., Zhang S. \& Huang J. (2015). - Emerging and endemic types of Ostreid herpesvirus 1 were detected in bivalves in China. J. Invertebr. Pathol., 124, 98106. doi:10.1016/j.jip.2014.11.007.

100. Ren W., Chen H., Renault T., Cai Y., Bai C., Wang C. \& Huang J. (2013). - Complete genome sequence of acute viral necrosis virus associated with massive mortality outbreaks in the Chinese scallop, Chlamys farreri. Virol J., 10, 110. doi:10.1186/1743-422X-10-110. 
